\title{
PENGARUH PENEMPATAN KERJA DAN KOMPENSASI TERHADAP KINERJA KARYAWAN
}

\author{
M.S.A. Setiawan ${ }^{1}$, I.W. Bagia ${ }^{2}$ \\ 1,2Jurusan Manajemen, Universitas Pendidikan Ganesha, Singaraja \\ e-mail:kadeksarwaadi@yahoo.com,iwayanbagia@undiksha.ac.id
}

\begin{abstract}
Abstrak
Peneiltian ini bertujuan untuk memperoleh pengaruh: 1) Penempatan dan kompensasi terhadap kinerja karyawan, (2) Penempatan terhadap kompensasi karyawan, (3) Penempatan terhadap kinerja karyawan, dan (4) Kompensasi terhadap kinerja karyawan pada Sea Breeze Lovina. Desain penelitian yang digunakan adalah desain penelitian kuantitatif kausal dengan menggunakan analisis jalur (path analysis), serta pengoperasian penghitungannya menggunakan program Statistical Package for Social Sience (SPSS) 16.0 for Windows. Penelitian ini dilaksanakan di Sea Breeze Lovina dengan mengambil seluruh populasi berjumlah 32 karyawan dan objeknya adalah penempatan kerja, kompensasi, dan kinerja karyawan. Hasil penelitian ini adalah sebagai berikut (1) penempatan dan kompensasi berpengaruh positif terhadap kinerja karyawan sebesar 94,60\%, (2) penempatan berpengaruh positif terhadap kompensasi karyawan sebesar $90,10 \%$, (3) penempatan berpengaruh positif terhadap kinerja karyawan sebesar $36,60 \%$, dan (4) kompensasi berpengaruh positif terhadap kinerja karyawan sebesar $67,00 \%$ pada Sea Breeze Lovina.
\end{abstract}

Kata kunci : kinerja karyawan, kompensasi, penempatan

\section{Abstract}

This research aims to influence: 1) placement and compensation on employee performance, (2) work placement on employee compensation, (3) work placement on employee performance, and (4) compensation for employee performance at Sea Breeze Lovina. The research design used is a causal quantitative, research design using path analysis and the calculation operation uses the Statistical Package for Social Science (SPSS) 16.0 for Windows program. This research was conducted at Sea Breeze Lovina by taking the entire population of 32 employees and the objects were placement, compensation, and employee performance. The results of this study are as follows: (1) placement and compensation have a positive effect on employee performance by $94.60 \%$, (2) placement has a positive effect on employee compensation by $90.10 \%$, (3) placement has a positive effect on performance employees of $36.60 \%$, and (4) compensation has a positive effect on employee performance by $67.00 \%$ at Sea Breeze Lovina.

Keywords : compensation, employee performance, placement

\section{Pendahuluan}

Sumber daya manusia yang unggul dan berkualitas dapat dilihat dari kinerjanya. Kinerja karyawan dipengaruhi oleh variabel penempatan kerja dan kompensasi. Kinerja karyawan akan meningkat bila perusahaan melakukan penempatan karyawan sesuai kemampuan yang dimiliki dan meningkatkan gaji karyawan. Hal ini dipertegas oleh Ardana (2012: 124) menyatakan bahwa "jika penempatan kerja dan kompensasi karyawan sesuai maka akan meningkatkan kinerja karyawan".

Sea Breeze Lovina adalah restuarant dan bar di pinggir pantai Lovina di di Jalan Binaria Centeral Lovina. Sea Breeze Lovina memiliki beberapa Departement diatarannya adalah Housekeping, Security, F\&B Servis, Bar, dan F\&B Produk. Memuaskan para pengunjung diperlukan sumber daya manusia yang memiliki penempatan kerja yang baik. Sea Breeze Lovina menetapkan standar kinerja bagi setiap karyawan yang ada dalam perusahaan tersebut karena akan berpengaruh terhadap kompensasi yang mereka terima. Pemberian kompensasi yang sama ini menandakan bahwa semua karyawan wajib untuk berkerja sama untuk mencapai target yang di targetkan perusahaan. Hasil observasi awal yang telah dilakukan di tiga hotel yaitu, (1) Sea Breeze Lovina, (2) Lovina Life, dan (3) Astina 
Restaurant, terlihat bahwa Sea Breeze Lovina tidak sesuai kinerja perusahaan yang telah ditentukan oleh hotel.

Kinerja merupakan outcome dari pencapaian/prestasi karyawan berkenaan dengan tugas-tugas yang dibebankan kepadanya. Dimensi kinerja yang digunakan dalam penelitian ini mengacu pada pendapat yang disampaikan Wirawan (2009) yaitu: (1) hasil kerja, (2) perilaku (proses) kerja, dan (3) sifat pribadi. Menurut Wirawan (2009) menyatakan bahwa ada 3 indikator kinerja karyawan yaitu (1) hasil kerja yang meliputi kualitas hasil kerja karyawan, kuantitas hasil kerja karyawan, dan efisiensi karyawan dalam melakasanakan tugas yang diberikan oleh perusahaan. (2) perilaku/proses kerja yang meliputi disiplin kerja karyawan seperti menaati aturan jam kerja, tidak merokok saat bekerja, dan berpakaian rapi, karyawan memberikan inisiatif kepada perusahaan agar perusahaan mampu meningkatkan kinerjanya, dan karyawan harus menjaga kesetiaannya terhadap perusahaan. (3) sikap pribadi yang meliputi kepercayaan diri karyawan yang tinggi, tanggung jawab karyawan terhadap pekerjaan, dan kerja sama karyawan antara perusahaan dan rekan kerja. Pendapat yang tidak jauh berbeda diungkapkan Harry (2013: 117) menyatakan bahwa indikator dari kinerja karyawan yaitu (1) kualitas kerja meliputi lamanya waktu kerja yang dipergunakan oleh karyawan dan banyaknya kesalahan yang diperbuat saat bekerja, (2) kuantitas kerja karyawan meliputi kuantitas pekerjaan dari karyawan tersebut, (3) pengetahuan kerja meliputi pemahaman dan pengetahuan karyawan dalam bekerja sehingga pekerjaan mampu selesai dengan cepat, (4) kreativitas kerja meliputi gagasan-gagasan yang muncul dan tindakan-tindakan karyawan yang mampu memnyelesaikan masalah pekerjaan yang dihadapi perusahaan. Indikator kinerja yang digunakan dalam penelitian ini adalah (1) hasil kerja yang meliputi kualitas hasil kerja karyawan, kuantitas hasil kerja karyawan, dan efisiensi karyawan dalam melakasanakan tugas yang diberikan oleh perusahaan. (2) perilaku/proses kerja yang meliputi disiplin kerja karyawan seperti menaati aturan jam kerja, tidak merokok saat bekerja, dan berpakaian rapi, karyawan memberikan inisiatif kepada perusahaan agar perusahaan mampu meningkatkan kinerjanya, dan karyawan harus menjaga kesetiaannya terhadap perusahaan. (3) sikap pribadi yang meliputi kepercayaan diri karyawan yang tinggi, tanggung jawab karyawan terhadap pekerjaan, dan kerja sama karyawan antara perusahaan dan rekan kerja. Dalam penelitian ini dimensi dan indikator kompensasi yang digunakan mengacu pendapat dari Wirawan (2009).

Pada Sea Breeze Lovina belum tercapai standar pencapaian kinerja karyawan. Oleh karena itu, penelitian ini dilakukan di Sea Breeze Lovina. Sea Breeze Lovina memiliki jumlah karyawan sebanyak 32 orang. Berdarkan observasi awal yang dilakukan menyatakan bahwa karyawan Sea Breeze tidak memenuhi SOP yang ditetapkan oleh perusahaan, maka dari itu perusahan akan mengalami penurunan hasil kinerja karyawan. Observasi awal mengenai kinerja karyawan pada 10 orang karyawan dari departemen, diketahui bahwa pencapaian kinerja karyawan Sea Breeze Lovina masih dalam kategori belum tercapai standar.

Penempatan kerja adalah proses pemberian pekerjaan terhadap karyawan baru sesuai dengan ruang lingkung dan mampu bertanggung jawab terhadap tugas dan pekerjaannya (Siswanto, 2012). Pendapat yang tidak jauh berbeda diungkapkan Suwatno (2003: 129) menyatakan bahwa dimensi penempatan kerja meliputi (1) pendidikan karyawan, (2) keterampilan kerja karyawan, (3) pengalaman kerja. Pendapat yang tidak jauh berbeda diungkapkan oleh Hartatik (2014) dimensi penempatan kerja yaitu (1) kemampuan, (2) kecakapan, (3) keahlian. Pendapat yang tidak jauh berbeda diungkapkan Wahyudi (2002: 123) mengemukakan dimensi penempatan kerja yaitu (1) pendidikan karyawan, (2) pengetahuan kerja karyawan terhadap pekerjaannya. (3) keterampilan kerja karyawan, dan (4) pengalaman kerja karyawan. Dimensi penempatan kerja penelitian ini adalah (1) pendidikan, (2) keterampilan kerja, (3) pengalaman kerja. Indikator penempatan kerja menurut Hartatik (2014) indikator penempatan kerja yaitu (1) kemampuan, (2) kecakapan, (3) keahlian. Indikator penempatan kerja penelitian ini diantaranya yaitu (1) pendidikan, (2) keterampilan kerja, (3) pengalaman kerja. Dalam penelitian ini dimensi dan indikator penempatan kerja yang digunakan mengacu pendapat dari Suwatno (2003: 129). Penempatan kerja yang tidak sesuai dengan keahliannya maka akan mengakibatkan 
penurunan kinerja karyawan. Observasi awal mengenai penempatan kerja karyawan pada 10 orang karyawan pada Sea Breeze Lovina masih dalam kategori tidak sesuai standar.

Penyebab kinerja karyawan menurun yaitu ketidaksesuaian kompensasi. Kompensasi adalah segala sesuatu yang diterima oleh karyawan yang berbentuk uang, barang langsung atau barang tidak langsung sebagai balas jasa yang diberikan oleh perusahaan atas pekerjaan yang dilakukan di perusahaan. Dimensi kompensasi adalah (a) kompensasi financial dan (b) kompensasi non finansial. Pendapat tersebut juga didukung pula oleh Sunyoto (2012) mengungkapkan bahwa indikator kompensasi terdiri dari (1) kompensasi finansial, dan (2) kompensasi non finansial. Indikator kompensasi menurut Simamora (2006) diantaranya yaitu: (1) gaji yang diterima karyawan, (2) insentif yang diterima karyawan, (3) tunjangan yang diterima karyawan, dan (4) fasilitas yang diterima karyawan. Menurut Sunyoto (2012) mengungkapkan bahwa indikator kompensasi terdiri dari (1) kompensasi finansial meliputi: gaji karyawan yang diterima dan yang diharapkan, bonus yang akan diterima karyawan, tunjangan hari raya karyawan, tunjangan hari tua bagi karyawan yang sudah lama bekerja di perusahaan, jaminan kesehatan karyawan, jaminan keselamatan kerja, dan lain-lain, (2) kompensasi non finansial adalah kompensasi yang diterima oleh karyawan dalam bentuk selain uang seperti menciptakan kondisi kerja yang menyenangkan, memberikan promosi jabatan, dan memberikan program rekreasi. Hal ini berguna untuk mempertahankan karyawan di perusahaan dalam jangka waktu panjang. Indikator kompensasi yang digunakan dalam penelitian ini yaitu: (1) gaji, (2) insentif, (3) tunjangan, dan (4) fasilitas. Dalam penelitian ini dimensi dan indikator kompensasi mengacu pendapat dari Simamora (2006). Kompensasi finansial para karyawan Sea Breeze Lovina tidak sesuai dengan UMR. Kompensasi finansial diberikan pada karyawan tidak boleh diberikan dibawah dari UMR karena kompensasi finansial adalah salah satu bentuk kerja keras karyawan. Faktor kompensasi non finansial juga mampu meningkatkan kinerja karyawannya.

Hasil observasi awal kompensasi non finansial yang dilakukan pada Sea Breeze Lovina menggambarkan ruangan/tempat kerja belum sesuai kebutuhan karyawan seperti ruang kerja masih sempit, sirkulasi udaranya masih kurang sehingga karyawan tidak nyaman dengan kondisi ruangan yang menyebabkan karyawan tidak fokus dalam bekerja sehingga dapat menurunkan kinerja karyawan pada Sea Breeze Lovina. Rendahnya tingkat pendidikan karyawan Sea Breeze Lovina sehingga memungkinkan para karyawan bekerja tidak optimal. Berdasarkan Standard Operating Procedures (SOP) Sea Breeze, standar pendidikan Sea Breeze minimal Diploma 3 Perhotelan, sedangkan tingkat pendidikan karyawan masih dibawah standar pendidikan yang ditentukan oleh Sea Breeze maka dari itu Sea Breeze perlu memberikan pelatihan terhadap karyawannya

Pemaparan di atas maka dapat ditarik hipotesis sebagai berikut.

$\mathrm{H}_{1}: \mathrm{X}_{1}$ dan $\mathrm{X}_{2}$ berpengaruh positif terhadap $\mathrm{Y}$

Hipotesis yang pertama yaitu pengaruh penempatan kerja dan kompensasi terhadap kinerja. Kinerja akan meningkat jika penempatan kerja sesuai dengan standar pendidikan yang ditentukan dan pemberian kompensasi yang sesuai dengan UMR atau tugas yang diberikan kepada karyawannya. Didukung oleh Ardana (2012: 124) yang menyatakan bahwa kedua variabel bebas tersebut akan mempengaruhi peningkatan kinerja karyawan. Kajian empirik yang mendukung yaitu menurut Agusri (2018) yang menyatakan bahwa kedua variabel bebas ini yaitu penempatan kerja dan kompensasi sesuai dengan standar pendidikannya dan tugas yang diberikan maka akan berpengaruh positif terhadap kinerja yang akan membuat para karyawan bekerja secara maksimal. Maka dari itu didapatkan hipotesis pertama yaitu kedua variabel bebas yang digunakan berpengaruh positif terhadap peningkatan kinerja karyawan.

$\mathrm{H}_{2}$ : Pengaruh positif $\mathrm{X}_{1}$ terhadap $\mathrm{X}_{2}$.

Penempatan kerja berhubungan erat dengan kompensasi kerja karena jika penempatan kerja karyawan tidak sesuai dengan kemampuan yang dimiliki maka akan mempengaruhi kompensasi kerja karyawan. Hal ini di dukung oleh Pramono (2016) menyatakan bahwa $X_{1}$ mempengaruhi $X_{2}$. Dimana penempatan kerja karyawan harusnya sesuai dengan standar perusahaan sehingga kompensasi yang didapatkan akan sesuai dengan keinginan yang karyawan inginkan. Teori ini didukung penelitian emperik dari 
Posuma (2013), dan Atkhan (2013) yang menyatakan kedua variabel bebas ini saling berpengaruh yaitu penempatan kerja berpengaruh terhadap kompensasi yang bermanfaat bagi perusahaan. Maka dari itu didapatkan hipotesis kedua yaitu variabel bebas seperti penempatan kerja yang digunakan berpengaruh positif terhadap kompensasi.

$\mathrm{H}_{3}$ : Pengaruh positif $\mathrm{X}_{1}$ terhadap $\mathrm{Y}$

Hipotesis ketiga yaitu pengaruh penempatan kerja dengan variabel terikat dalam penelitian ini karena jika penempatan kerja dalam perusahaan tidak seusai maka kinerja karyawan akan tidak optimal yang akan merugikan perusahaan. Maka dari itu, karyawan baru harusnya diberikan pelatihan atau disesuaikan dengan kemampuan yang dimilikinya. $\mathrm{Hal}$ ini teori yang mendukung dikatakan oleh Aldilaningsari (2014) mengungkapkan bahwa kinerja perushaan akan meningkat jika perusahaan memperhatikan penempatan kerja karyawan. Hal ini kajian empirik dikatakan oleh Atkhan (2013) bahwa variabel bebas yang pertama yaitu penempatan kerja mampu mempengaruhi peningkatan kinerja. Maka dari itu didapatkan hipotesis ketiga yaitu variabel bebas seperti penempatan kerja yang digunakan berpengaruh positif terhadap kinerja karyawan.

$\mathrm{H}_{4}$ : Pengaruh positif $\mathrm{X}_{2}$ terhadap $\mathrm{Y}$.

Hipotesis yang terakhir yaitu pengaruh positif kompensasi terhadap kinerja. Jika kompensasi yang diberikan perusahaan sesuai dengan yang diinginkan karyawan maka tugas yang diberikan akan lebih cepat selesai sehingga kinerja akan meningkat secara maksimal. Hal ini didukung oleh teori Hasibuan (2009: 117) menyatakan bahwa jika kompensasi sesuai dengan UMR maka akan meningkatkan kinerja karyawan. Kajian emperik diatas didukung oleh Suwati (2013) yang menyatakan bahwa variabel bebas kedua yang digunakan dalam penelitian ini akan berpengaruh positif dengan peningkatan kinerja. Jadi hipotesis keempat yaitu variabel bebas kedua yang digunakan dalam penelitian ini berpengaruh positif terhadap peningkatan kinerja karyawan.

Maka dari itu penulis tetarik untuk penelitian dengan judul "Pengaruh Penempatan Kerja dan Kompensasi terhadap Kinerja Karyawan pada Sea Breeze Lovina". Identifikasi masalah penelitian ini dibatasi untuk meneliti masalah kinerja karyawan, penempatan kerja, dan kompensasi.

Identifikasi masalah pada Sea Breeze Lovina sebagai berikut (1) kinerja karyawan pada Sea Breeze Lovina dikategorikan belum tercapai karena capaian kinerja karyawan masih dibawah standar kinerja karyawan yang ditetapkan oleh pihak perusahaan. (2) Penempatan kerja tidak sesuai dengan pekerjaannya saat ini. Observasi awal yang memperlihatkan bahwa pekerjaan karyawan saat ini tidak sesuai dengan kemampuan karyawan. (3) Kompensasi finansial karyawan yang masih tidak sesuai dengan UMR. (4) Tingkat pendidikan karyawan yang masih belum sesuai dengan standar tingkat pendidikan yang ditentukan oleh perusahaan.

Dari latar belakang tersebut, dapat ditarik rumusan masalah yaitu (1) Bagaimana pengaruh penempatan kerja dan kompensasi terhadap kinerja karyawan pada Sea Breeze Lovina? (2) Bagaimana pengaruh penempatan kerja terhadap kompensasi pada Sea Breeze Lovina? (3) Bagaimana pengaruh penempatan kerja terhadap kinerja karyawan pada Sea Breeze Lovina? (4) Bagaimana pengaruh kompensasi terhadap kinerja karyawan pada Sea Breeze Lovina?

Tujuan penelitian ini untuk mengetahui pengaruh dari (1) Penempatan kerja dan kompensasi terhadap kinerja karyawan pada Sea Breeze Lovina, (2) Penempatan kerja terhadap kompensasi pada Sea Breeze Lovina, (3) Penempatan kerja terhadap kinerja karyawan pada Sea Breeze Lovina, (4) Kompensasi terhadap kinerja karyawan pada Sea Breeze Lovina.

Penelitian ini akan memberikan manfaat bagi perusahaan. Manfaat yang diberikan dibagi menjadi 2 (dua) yaitu manfaat teoritis dan manfaat praktis. Manfaat teoritis yaitu mampu memberikan dan mengembangkan ilmu-ilmu manajemen terutama dibidang sumber daya manusia mengenai penempatan kerja, kompensasi, dan kinerja karyawan. Manfaat praktis yang diberikan yaitu pihak pengelola pengelola Sea Breeze Lovina sebaiknya mempertimbangkan segala saran/masukan mengenai penempatan kerja, kompensasi, dan 
kinerja karyawan yang nantinya akan berguna bagi kebijakan yang berlaku pada Sea Breeze Lovina.

\section{Metode}

Penelitian ini menggunakan desain kuantitatif kausal, dimana kuantitatif kausal merupakan pengambilan keputusan manajerial yang bermaksud untuk mmeperoleh buktibukti, hubungan sebab akibat antar variabel, atau mengetahui pengaruh dari variabel. Maka dari itu dalam penelitian ini menggunakan variabel bebas pertama yaitu penempatan kerja, variabel bebas kedua yaitu kompensasi, dan variabel terikatnya adalah kinerja karyawan. Dimana penelitian ini dilakukan pada Sea Breeze Lovina dengan jumlah karyawan 32 orang. Penelitian ini menggunakan populasi karena dalam penelitian ini menggunakan seluruh karyawan yang bekerja di Sea Breeze Lovina. Jenis data yang diperoleh berasal dari seluruh karyawan Sea Breeze Lovina. Upaya yang dilakukan dalam pengumpulan data yaitu (1) kuesioner, dimana kuesioner dibagikan pada seluruh karyawan mengenai penempatan kerja kompensasi, dan kinerja karyawan. (2) pencatatan dokumen, dimana dokumen/arsip-arsip dicatat oleh peneliti seperti gaji karyawan, jumlah karyawan, dan nama karyawan. Dalam penelitian ini, menggunakan analisis data yaitu analisis jalur (Path Analysis). Analisis jalur (Path Analysis) merupakan pola yang digunakan menganalisis hubungan yang tidak langsung dan analisis ini merupakan pengembangan analisis berganda. Data yang diperoleh dari kuesioner akan diolah menggunakan bantuan program SPSS versi 16.0.

\section{Hasil dan Pembahasan}

Hasil penelitian mengenai penempatan kerja, kompensasi dan kinerja karyawan dapat dilihat pada Tabel 1.

Tabel 1

Output SPSS Penempatan Kerja dan Kompensasi terhadap Kinerja Karyawan Sea Breeze Lovina

\begin{tabular}{|c|c|c|}
\hline Parameter & Koefisien & Simpulan \\
\hline $\operatorname{Ryx}_{1} x_{2}$ & 0,946 & Variabel bebas berpengaruh positif terhadap variabel terikat \\
\hline $\mathrm{R}^{2} \mathrm{yx}_{1} \mathrm{x}_{2}$ & 0,895 & Besar sumbangan variabel bebas terhadap variabel terikat \\
\hline $\mathrm{Pyx}_{1}$ & 0,366 & Penempatan kerja berpengaruh positif terhadap variabel terikat \\
\hline$P^{2} \mathrm{yx}_{1}$ & 0,134 & $\begin{array}{l}\text { Besar sumbangan pengaruh penempatan kerja terhadap } \\
\text { variabel terikat }\end{array}$ \\
\hline $\mathrm{Pyx}_{2}$ & 0,670 & Kompensasi berpengaruh positif terhadap variabel terikat \\
\hline$P^{2} y_{2}$ & 0,449 & $\begin{array}{l}\text { Besar sumbangan pengaruh kompensasi terhadap variabel } \\
\text { terikat }\end{array}$ \\
\hline $\mathrm{Px}_{2} \mathrm{X}_{1}$ & 0,901 & Penempatan kerja berpengaruh positif terhadap Kompensasi \\
\hline$P^{2} x_{2} X_{1}$ & 0,812 & $\begin{array}{l}\text { Besar sumbangan pengaruh kenempatan kerja terhadap } \\
\text { kompensasi }\end{array}$ \\
\hline Py $\varepsilon_{2}$ & 0,105 & Variabel lain berpengaruh terhadap $Y$ \\
\hline$P x_{2} \varepsilon_{1}$ & 0,188 & Variabel lain berpengaruh terhadap $\mathrm{X}_{2}$ \\
\hline
\end{tabular}

Sumber : Pengolahan Data SPSS 16.0 For Windows

Pengaruh masing-masing variabel penempatan kerja, kompensasi terhadap kinerja karyawan di Sea Breeze Lovina dapat digambarkan pada Gambar 1. 


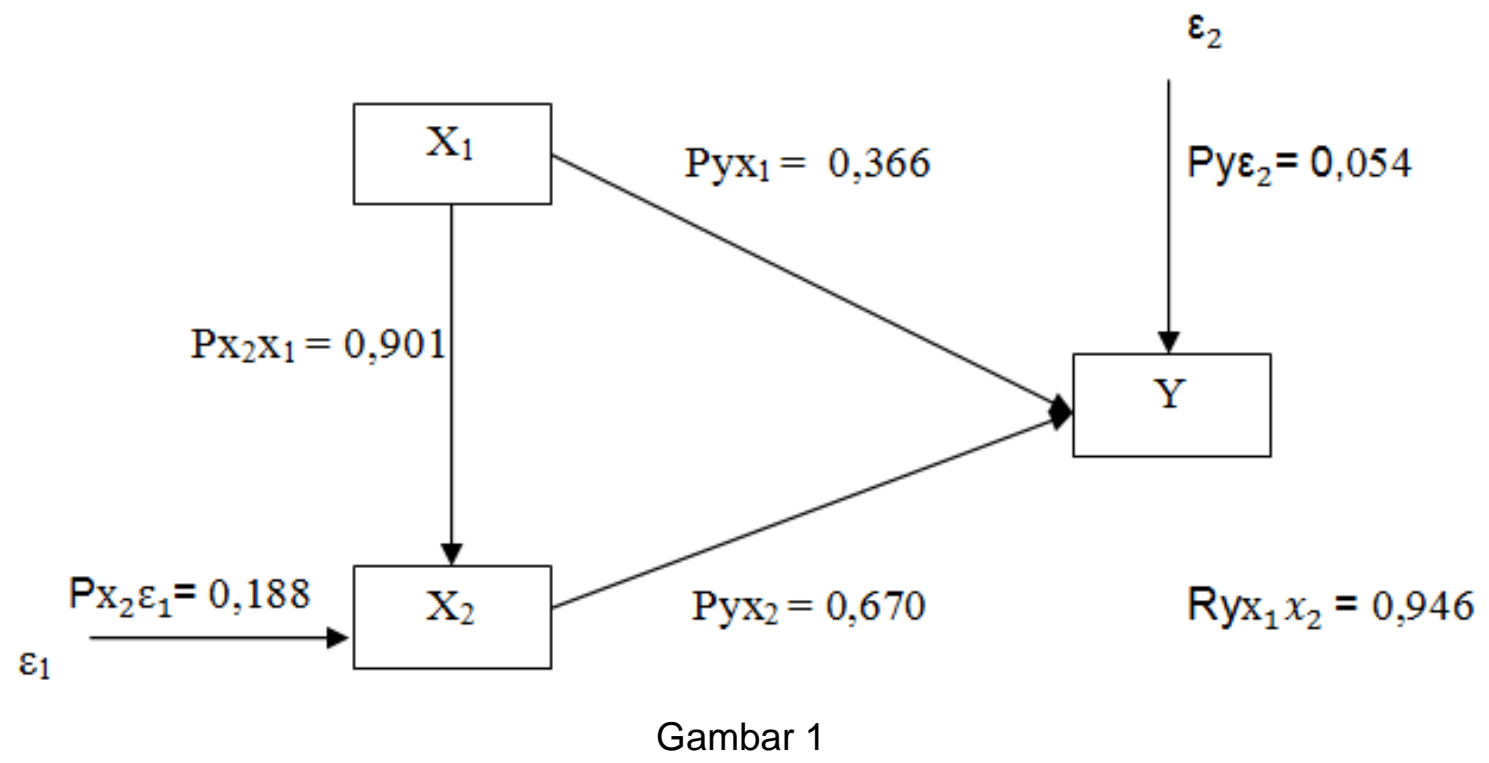

Hubungan Pengaruh Penempatan kerja $\left(X_{1}\right)$ dan Kompensasi $\left(X_{2}\right)$ Terhadap Kinerja Karyawan (Y) di Sea Breeze Lovina.

Berdasarkan hasil penelitian, besar sumbangan langsung maupun tidak langsung dari penempatan kerja dan kompensasi terhadap kinerja dapat dilihat pada Tabel 2 sebagai berikut.

Tabel 2

Sumbangan Pengaruh Variabel Penempatan kerja $\left(\mathrm{X}_{1}\right)$ dan Kompensasi $\left(\mathrm{X}_{2}\right)$ Terhadap Kinerja (Y)

\begin{tabular}{lcc}
\hline \multicolumn{1}{c}{ Keterangan } & Besar Sumbangan & Persentase \\
\hline $\begin{array}{l}\text { Pengaruh langsung penempatan kerja terhadap } \\
\text { kinerja }\end{array}$ & 0,134 & $13,40 \%$ \\
$\begin{array}{l}\text { Pengaruh tidak langsung penempatan kerja } \\
\text { terhadap kinerja melalui kompensasi }\end{array}$ & 0,312 & $31,20 \%$ \\
Pengaruh total $X_{1}$ terhadapY & & \\
Pengaruh langsung $X_{2}$ terhadap $Y$ & 0,446 & $44,60 \%$ \\
Pengaruh total $X_{1}$ dan $X_{2}$ terhadap $Y$ & 0,449 & $44,90 \%$ \\
Pengaruh lain $X_{1}$ dan $X_{2}$ terhadap $Y$ & 0,895 & $89,50 \%$ \\
\hline
\end{tabular}

Hasil pengolahan data menggunakan analisis jalur, penempatan kerja dan kompensasi berpengaruh secara positif terhadap variabel terikat sebesar 0,946, sedangkan besar sumbangan pengaruh penempatan kerja dan kompensasi terhadap variabel terikat sebesar 0,895 . Hipotesisnya Menolak Ho yang artinya $X_{1}$ dan $X_{2}$ berpengaruh terhadap $Y$. Hal tersebut ditunjukkan dengan $p$-value $\operatorname{Ryx}_{1} \mathrm{x}_{2}=0,000<\alpha=0,05$. Temuan ini memberi arti bahwa penempatan kerja dan kompensasi berpengaruh terhadap kinerja karyawan. Kinerja juga dipengaruhi oleh beberapa varibel yang menyebabkan kinerja itu menurun yaitu tingkat pendidikan, budaya organisasi, kepemimpinan, dan lingkungan kerja (Khomsahrial, 2012).

Berdasarkan hasil pengolahan data menggunakan analisis jalur, penempatan kerja berpengaruh secara positif terhadap variabel terikat sebesar 0,366, sedangkan besar sumbangannya sebesar 0,134 . Hipotesisnya Menolak Ho yang artinya $X_{1}$ berpengaruh terhadap Y. Hal tersebut ditunjukkan dengan $p$-value Pyx $_{1}=0,000<\alpha=0,05$. Hasil penelitian ini, memberi arti bahwa penempatan kerja berpengaruh terhadap variabel terikat dalam penelitian ini. 
Berdasarkan hasil pengolahan data menggunakan analisis jalur, kompensasi berpengaruh secara positif terhadap variabel terikat sebesar 0,670, besar sumbangannya sebesar 0,449 . Hipotesisnya Menolak Ho yang artinya $X_{1}$ berpengaruh terhadap $Y$. Hal tersebut ditunjukkan dengan $p$-value $\mathrm{Pyx}_{2}=0,004<\alpha=0,05$. Hasil penelitian ini, memberi arti bahwa $X_{2}$ berpengaruh terhadap variabel terikat.

Berdasarkan hasil pengolahan data menggunakan analisis jalur, penempatan kerja berpengaruh secara positif terhadap kompensasi karyawan sebesar 0,901, sedangkan besar sumbangannya sebesar 0,812. Hipotesisnya Menolak Ho yang artinya $X_{1}$ berpengaruh terhadap $\mathrm{Y}$. Hal tersebut ditunjukkan dengan $p$-value $\mathrm{Px}_{2} \mathrm{x}_{1}=0,000<\alpha=0,05$. Hasil penelitian memberi arti bahwa penempatan kerja berpengaruh terhadap kompensasi. Disiplin kerja dapat dipengaruhi variabel lain seperti lingkungan dan pelatihan (Hasibuan, 2009)

Penelitian ini akan memperoleh hasil yang pertama yaitu kedua variabel seperti penempatan kerja dan kompensasi akan mempengaruhi kinerja karyawan. Dimana hal tersebut dilihat dari hasil penelitian dan teori yang mendukung. Teori yang mendukung dari penelitian ini dari Ardana (2012: 124) yang menyatakan bahwa jika penempatan kerja dan kompensasi didpat tidak sesuai dengan yang diinginkan maka akan berdampak merugikan karyawan, Hal ini didukung oelh penelitian kenerja oleh Agusri (2018) Agusri (2018) yang menyatakan bahwa kedua variabel ini dapat meningkatkan kinerja

Penelitian ini akan memperoleh hasil yang kedua yaitu pengaruh penempatan kerja terhadap kompensasi karyawan Sea Breeze Lovina. Hal ini ditunjukkan dan didukung dari pendapat Pramono (2016) yang menyatakan bahwa penempatan kerja yang sesuai dengan kemampuannya maka kompensasi akan diberikan sesuai dengan tugas yang mampu diselesaikan. Apabila penempatan kerja dan kompensasi meningkat, maka kinerja karyawan akan meningkat dan menguntungkan perusahaan. Kajian empirik diatas mendukung penelitian dari Posuma (2013) dan Atkhan (2013) yang menyatakan jika penempatan kerja sesuai dengan kompensasi yang didapat maka karyawan akan senang dan akan meningkatkan kinerja karyawan.

Penelitian ini akan memperoleh hasil yang ketiga yaitu pengaruh penempatan kerja terhadap kinerja. Hal tersebut, dilihat dari hasil penelitian dan didukung oleh Aldilaningsari (2014) yang mengatakan bahwa apabila penempatan kerja karyawan tidak sesuai dengan pendidikannya maka akan menyebabkan karyawan kurang optimal dalam mengerjakan tugasnya sehingga kinerja tidak mampu meningkat. Teori tersebut didukung oleh kajian empirik dari Atkhan (2013) menyatakan bahwa penempatan kerja harus sesuai dengan pendidikannya sehingga karyawan mampu bekerja dengan baik, sehingga mampu menyelesaikan tugasnya dengan tepat waktu.

Penelitian ini akan memperoleh hasil yang keempat yaitu variabel $x_{2}$ berpengaruh terhadap kinerja karyawan. Hal ini mendukung teori dari Simmora (2004) yang mengatakan bahwa kompensasi yang diberikan secara finansial dan non finansial penting bagi kebutuhan karyawan. Teori diatas didukung dari penelitian Suwati (2013) yang mengatakan bahwa kompensasi sangat berhubungan dengan kinerja karyawan. Oleh karena itu, kompensasi berpengaruh terhadap peningkatan kinerja karyawan.

Penelitian ini masih dalam kategori sempit dikarenakan variabel yang diuji masih sedikit dan populasi yang masih sedikit. Diharapkan penguji selanjutnya, untuk menguji subjek yang lebih besar dan variabel lain yang akan mempengaruhi peningkatkan kinerja seperti gaya kepemimpinan, promosi jabata, dan budaya kerja.

\section{Simpulan dan Saran}

Kesimpulan yang diperoleh dari penelitian ini yaitu (1) kedua variabel bebas ini seperti penempatan kerja dan kompensasi menunjukkan bahwa kedua variabel tersebut dapat meningkatkan kinerja karyawan. (2) variabel penempatan kerja berpengaruh positif terhadap kompensasi Sea Breeze Lovina. Temuan ini memiliki arti bahwa penempatan kerja berperan dalam upaya peningkatan kompensasi karyawan di Sea Breeze Lovina. (3) variabel penempatan kerja secara parsial akan mempengaruhi peningkatan kinerja karyawan pada 
Sea Breeze Lovina. (4) Variabel kompensasi secara parsial juga akan mempengaruhi peningkatan kinerja karyawan pada Sea Breeze Lovina.

Penelitian ini akan memberikan saran/masukan pada Sea Breeze Lovina yang akan berguna untuk meningkatkan kinerja karyawan Sea Breeze Lovina. Diharapkan manajer Sea Breeze Lovina lebih memperhatikan penempatan kerja dan kompensasi karyawannya. Penempatan kerja dapat ditingkatkan dengan cara (a) merekrut karyawan sesuai dengan pendidikan yang dimiliki, (b) memberikan pelatihan kerja terhadap karyawan baru yang akan berguna untuk meningkatkan keahlian karyawan sehingga karyawan akan bekerja semaksimal mungkin, (c) meberikan gaji karyawan yang sesuai dengan UMK atau sesuai dengan pekerjaan yang diberikan atasan, serta (d) memberikan tunjangan kepada karyawan atas kinerjanya yang akan membuat karyawan termotivasi untuk lebih giat dalam menyelesaikan tugasnya sehingga dapat meningkatkan kinerja secara otomatis akan menguntungkan perusahaan. Saran yang akan diberikan kepada pelitian selanjutnya yaitu mengembangkan yang akan diuji yang akan mempengaruhi kinerja karyawan Sea Breeze Lovina seperti promosi jabatan, budaya kerja, dan kepemimpinan.

\section{Daftar Pustaka}

Agusri. 2018. Pengaruh Penempatan Kerja, Disiplin kerja, dan Kompensasi Terhadap Kinerja Karyawan PT. Bank Tabungan Negara (Persero) Tbk Cabang Palembang. Jurnal Media Wahana Ekonomika, Volume 15, No.2

Hartatik, Indah Puji. 2015. Buku Praktis Mengembangkan SDM. Yokyakarta: Laksana.

Khomsahrial, Romli. 2016. Komunikasi Organisasi Lengkap. Edisi Revisi. Jakarta: Gramedia Widiasarana Indonesia

Martoyo, Susilo. 2017. Manajemen Sumber Daya Manusia, Edisi 5, Cetakan Pertama. Yogyakarta: BPFE.

Pabundu, Tika. 2018. Budaya Organisasi Dan Peningkatan Kinerja Perusahaan. Jakrata: Bumi Aksara.

Panggabean. 2015. Manajemen Sumber Daya Manusia. Jakarta: Ghalia Indonesia.

Posuma, Christilia O. 2016. Penempatan kerja, Kompensasi dan Kepemimpinan Pengaruhnya terhadap Kinerja Karyawan pada Rumah Sakit Ratumbuysang Manado. Jurnal EMBA, Volume 1, Nomor 4

Priansa, Donni Juni. 2017. Manajemen SDM dalam Organisasi Publik dan Bisnis. Bandung: Alfabeta.

Pramono, Anggoro Jati. 2016. Pengaruh Penempatan Pegawai dan Kompensasi Terhadap Kinerja Pada KUDAM XII/TANJUNGPURA. Jurnal Magister Manajemen. Volume 2 No. 2

Rivai, Veithzal, 2015, Manajemen Sumber Daya Manusia Untuk Perusahaan, Cetakan Pertama. Jakarta: PT. Raja Grafindo Persada.

Rivai, Veithzal. 2010. Manajemen Sumber Daya Manusia Untuk Perusahaan. Jakarta: Rajawali Pers. 
Samsudin, Sadili. 2016. Manajemen Sumber Daya Manusia, Cetakan Pertama. Bandung: CV Pustaka Setia.

Simamora. 2017. Panduan Riset Perilaku Konsumen. Jakarta: Gramedia

Suwati, Yuli. 2017. Pengaruh Kompensasi dan Motivasi Kerja terhadap Kinerja Karyawan pada PT Tunas Hijau Samarinda. e-Jurnal IImu Administrasi Bisnis, Volume 1, Nomor 1

Sunyoto. 2015. Manajemen Sumber Daya Manusia. Yogyakarta: CAPS

Sedarmayanti. 2015. Manajemen Sumber Daya Manusia Reformasi Birokrasi dan Manajemen Pegawai Negeri Sipil. Bandung: PT Refika Aditama.

Suwatno. 2015. Asas-Asas Manajemen Sumber Daya Manusia. Bandung: Sucipress

Yani, H. M. 2016. Manajemen Sumber Daya Manusia. Jakarta: Mitra Wacana Media

Wahyudi, Bambang. 2017. Manajemen Sumber Daya Manusia. Jakarta: Sulita

Wibowo. 2017. Manajemen Kinerja. PT. Raja Grafindo Prasada Jakarta. 